\title{
SARS-CoV-2 Encephalitis Presenting as a Clinical Cerebellar Syndrome
}

\section{A Case Report}

Katryn Oosthuizen, MBChB, Elizabeth Christina Steyn, MBChB, Lawrence Tucker, MBChB, MSc, FCP(SA), PhD, Innocent Vusumusi Ncube, MBChB, FC Rad (Diag) MMed, Diana Hardie, MBChB, MMedPath, and

Suzaan Marais, MBChB, FC Neurol(SA), PhD

Neurology ${ }^{\circledR}$ 2021;97:27-29. doi:10.1212/WNL.0000000000012051

A 52-year-old previously healthy man was hospitalized with a 6-day history of progressive gait instability rendering him unable to walk. He reported no respiratory symptoms or fever. He was a smoker (5-10 pack-years) and consumed an undisclosed amount of alcohol over weekends for some years. At presentation, he was tachypneic $(20 \mathrm{bpm})$ and pyrexial $\left(37.7^{\circ} \mathrm{C}\right)$ but alert and oriented. He exhibited cerebellar signs, including multidirectional gaze-evoked nystagmus, dysarthria, and truncal and appendicular ataxia. His examination was otherwise normal.

Nasopharyngeal real-time polymerase chain reaction (RT-PCR) severe acute respiratory syndrome coronavirus 2 (SARS-CoV-2) testing was negative and chest radiograph showed nonspecific coarsening of bronchovascular markings. Uncontrasted CT brain revealed a central midbrain hypodensity but MRI was delayed due to resource constraints. Routine blood analyses were normal, apart from neutrophil predominant leukocytosis $\left(17 \times 10^{9} / \mathrm{L}\right)$ and elevated erythrocyte sedimentation rate $(72 \mathrm{~mm} / \mathrm{h})$. CSF analysis revealed pleocytosis (lymphocytes: $49 / \mu \mathrm{L}$, polymorphonuclear cells: $2 / \mu \mathrm{L})$ and increased immunoglobulin $\mathrm{G}$ index $(0.62$; normal $\leq 0.6)$; protein $(0.37 \mathrm{~g} / \mathrm{L})$, albumin $(157 \mathrm{mg} / \mathrm{L})$, and glucose $(3.6 \mathrm{mmol} / \mathrm{L})$ were normal. Tests for infections and malignancy were negative (e-Results, data available from Dryad: doi.org/10. 5061/dryad.pk0p2ngm7). Due to his alcohol use, thiamine $(500 \mathrm{mg} / \mathrm{d})$ was initiated.

The patient's ataxia improved marginally, but on day 7, he became severely agitated, lacked insight, and displayed fluctuating orientation. EEG was normal. Behavioral abnormalities were unresponsive to benzodiazepines and antipsychotics (olanzapine: $7.5 \mathrm{mg} / 5 \mathrm{mg}$ twice daily). MRI brain showed features consistent with brainstem encephalitis (figure, A-E). Corticosteroid therapy was delayed due to concern of increasing agitation and IV immunoglobulin was not offered as his behavior precluded IV therapy without prolonged physical restraint. Normal or negative blood investigations included tumor markers, infection and vasculitis screening, and autoimmune antibodies (e-Results, data available from Dryad: doi.org/10.5061/dryad.pk0p2ngm7). Serum screening for onconeural antibodies was positive for amphiphysin. Repeat CSF analysis on day 14 was normal. CT chest, abdomen, and pelvis identified no malignancy but revealed nonspecific ground-glass opacifications in lung periphery (figure, F) commonly seen in COVID-19 pneumonia. ${ }^{1}$

On day 17, respiratory RT-PCR testing for SARS-CoV-2 and serum SARS-CoV-2 antibodies were positive. Retrospective analyses of samples collected on admission detected SARS-CoV-2 RNA by RT-PCR in CSF (e-Results, data available from Dryad: doi.org/10.5061/dryad.pk0p2ngm7); SARS-CoV-2 antibodies were negative in serum. Behavioral abnormalities persisted until prednisone $(1 \mathrm{mg} / \mathrm{kg} / \mathrm{d})$ initiation but improved dramatically thereafter. Ataxia continued improving.

At discharge on day 36, the patient was walking independently. Mild emotional lability persisted. Six months later, repeat CSF examination remained normal (e-Results, data available from Dryad: doi. org/10.5061/dryad.pk0p2ngm7); contrasted CT chest and whole-body ${ }^{18}$ F-FDG PET/CT
Correspondence

Dr. Marais

marais.suzaan@gmail.com
MORE ONLINE

COVID-19 Resources

For the latest articles, invited commentaries, and blogs from physicians around the world NPub.org/COVID19

From the Division of Neurology, Department of Medicine (K.O., E.C.S., L.T., S.M.), Department of Radiology (I.V.N.), and Division of Virology, Department of Microbiology (D.H.), Groote Schuur Hospital and University of Cape Town; and Neurology Research Group (K.O., E.C.S., L.T., S.M.), UCT Neuroscience Institute, University of Cape Town, South Africa. Go to Neurology.org/N for full disclosures. Funding information and disclosures deemed relevant by the authors, if any, are provided at the end of the article. 

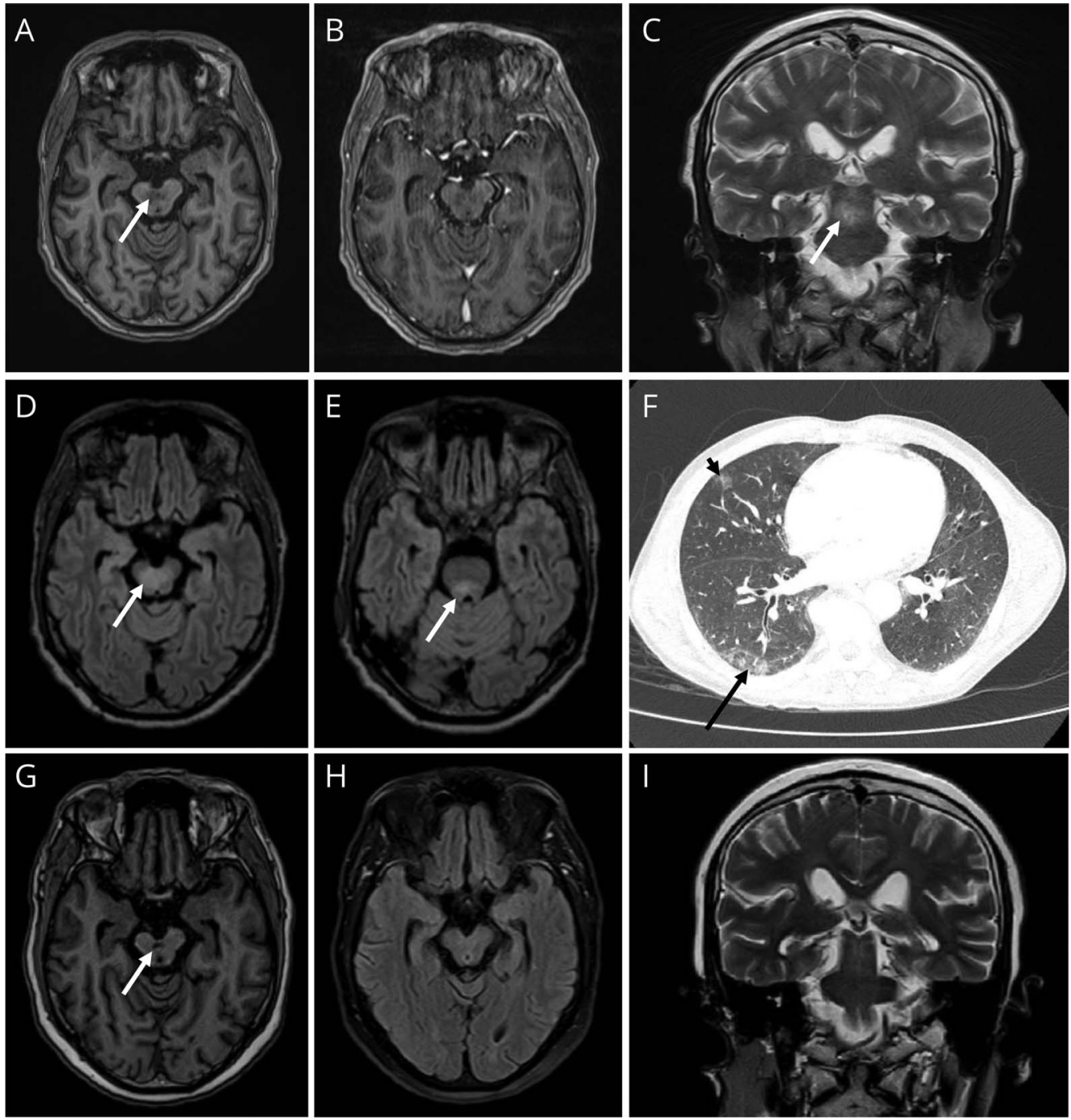

(A-E) Brain MRI at time of initial presentation, including (A) precontrast and (B) postcontrast T1-weighted, (C) T2-weighted, and (D, E) fluid-attenuated inversion recovery (FLAIR) images. All images are in the axial plane except C, which is in the coronal plane. Images demonstrate signal abnormality involving the central midbrain and dorsal pons (white arrows) that is hypointense on T1-weighted images, does not enhance after contrast administration, and is hyperintense on FLAIR and T2-weighted images. There was no restricted diffusion on diffusion-weighted imaging (not shown). (F) Axial postcontrast CT chest in lung window shows peripheral areas of patchy ground-glass opacification posteriorly (long arrow) and anteriorly (short arrow), findings commonly described in coronavirus disease 2019 (COVID-19) pneumonia, but also seen in atypical/other viral pneumonias and organizing pneumonias associated with conditions like drug toxicity and connective tissue disease. (G-I) Brain MRI performed 6 months after discharge, including (G) T1-weighted, (H) FLAIR, and (I) T2-weighted images, shows residual midbrain hypointensity on T1-weighted image (white arrow), but resolution of brainstem hyperintense signal on T2 and FLAIR images.

showed patchy postinfectious parenchymal lung changes, but no features of malignancy; and the previous MRI brainstem abnormalities had resolved (figure, G-I). At this time, all medication had been discontinued. The patient's mental state had normalized, but he exhibited mild residual cerebellar signs including dysarthria, appendicular ataxia, and a wide-based gait.

\section{Discussion}

Our patient meets case definition criteria for confirmed SARS-CoV-2 encephalitis, ${ }^{2}$ with evidence indicating neurologic manifestations occurring during acute infection. Detection of SARS-CoV-2 in CSF but not nasopharyngeal swab may reflect poor swab technique or, alternatively, a compartmental response with higher viral loads in CNS compared to upper airway during early disease. Cerebellar ataxia in patients with COVID-19 is increasingly described, but SARSCoV-2 has rarely been detected in CSF of previous cases tested, potentially reflecting sample collection timing or different pathogenic mechanisms. ${ }^{3-5}$

Although initial examination suggested pancerebellar dysfunction, imaging abnormalities were confined to the brainstem. Several reports have similarly shown clinicalradiologic disconnect in patients with COVID-19 with cerebellar signs, with MRI showing no abnormalities, or abnormalities located exclusively outside the cerebellum. ${ }^{3}$ 
Findings in our patient likely reflected involvement of brainstem-cerebellar connections, although additional direct cerebellar involvement cannot be excluded. COVID19 encephalitis may occur through direct viral damage, host immune responses, or a combination of factors. ${ }^{2}$ Immunotherapies are used to treat postinfectious immunemediated conditions. ${ }^{2}$ However, treatment of COVID-19 encephalitis during acute infection is controversial. Immunotherapies administered during active infection could potentially diminish the patient's antiviral response, exacerbating CNS disease. It is possible that SARS-CoV-2 directly caused neural dysfunction, given viral detection in CSF. However, the encephalopathy responded favorably to corticosteroids, suggesting host immune mechanisms contributed to disease pathogenesis.

The clinical significance of anti-amphiphysin antibodies was unclear given that no malignancy was identified. An association between viral infections and antibodies against cell surface antigens is well-documented. For example, herpes simplex encephalitis can trigger anti-NMDAR encephalitis, potentially through uncovering epitopes resulting in antibody responses. ${ }^{6,7}$ The possibility that SARS-CoV-2 encephalitis can induce responses against amphiphysin, an intracellular synaptic antigen, is intriguing and should be explored in future studies. $^{7}$

This report contributes to the rapidly expanding knowledge base of COVID-19-associated neurologic syndromes and highlights uncertainties regarding the pathogenesis of cerebellar dysfunction in, and optimal management of, patients with COVID-19-associated encephalitis.

\section{Study Funding}

The authors report no targeted funding.

\section{Disclosure}

The authors report no disclosures relevant to the manuscript. Go to Neurology.org/N for full disclosures.

\section{Publication History}

Received by Neurology September 18, 2020. Accepted in final form April 2, 2021.

Appendix Authors

\begin{tabular}{lll}
\hline Name & Location & Contribution \\
\hline $\begin{array}{l}\text { Katryn } \\
\text { Oosthuizen, } \\
\text { MBChB }\end{array}$ & $\begin{array}{l}\text { University of } \\
\text { Cape Town, } \\
\text { South Africa }\end{array}$ & $\begin{array}{l}\text { Major role in acquisition of data, } \\
\text { drafted the manuscript for } \\
\text { intellectual content }\end{array}$ \\
\hline $\begin{array}{l}\text { Elizabeth } \\
\text { Christina Steyn, } \\
\text { MBChB }\end{array}$ & $\begin{array}{l}\text { University of } \\
\text { Cape Town, } \\
\text { South Africa }\end{array}$ & $\begin{array}{l}\text { Major role in acquisition of data, } \\
\text { drafted the manuscript for } \\
\text { intellectual content }\end{array}$ \\
$\begin{array}{l}\text { Lawrence Tucker, } \\
\text { PhD }\end{array}$ & $\begin{array}{l}\text { University of } \\
\text { Cape Town, } \\
\text { South Africa }\end{array}$ & $\begin{array}{l}\text { Major role in acquisition of data, } \\
\text { revised the manuscript for } \\
\text { intellectual content }\end{array}$ \\
\hline $\begin{array}{l}\text { Innocent } \\
\text { Vusumusi Ncube, } \\
\text { FC Rad (diag) }\end{array}$ & $\begin{array}{l}\text { University of } \\
\text { Cape Town, } \\
\text { South Africa }\end{array}$ & $\begin{array}{l}\text { Interpreted the data, revised } \\
\text { the manuscript for intellectual } \\
\text { content }\end{array}$ \\
$\begin{array}{l}\text { Diana Hardie, } \\
\text { MMedPath }\end{array}$ & $\begin{array}{l}\text { University of } \\
\text { Cape Town, } \\
\text { South Africa }\end{array}$ & $\begin{array}{l}\text { Major role in acquisition of data, } \\
\text { interpreted the data, revised } \\
\text { the manuscript for intellectual } \\
\text { content }\end{array}$ \\
$\begin{array}{l}\text { Suzaan Marais, } \\
\text { PhD }\end{array}$ & $\begin{array}{l}\text { University of } \\
\text { Cape Town, } \\
\text { South Africa }\end{array}$ & $\begin{array}{l}\text { Designed and conceptualized } \\
\text { the study, analyzed the data, } \\
\text { drafted the manuscript for } \\
\text { intellectual content }\end{array}$ \\
\hline
\end{tabular}

\section{References}

1. Ye Z, Zhang Y, Wang Y, Huang Z, Song B. Chest CT manifestations of new coronavirus disease 2019 (COVID-19): a pictorial review. Eur Radiol 2020;30(8):4381-4389.

2. Ellul MA, Benjamin L, Singh B, et al. Neurological associations of COVID-19. Lancet Neurol 2020;19(9):767-783.

3. Chan JL, Murphy KA, Sarna JR. Myoclonus and cerebellar ataxia associated with COVID-19: a case report and systematic review. J Neurol. Epub 2020 Feb 22.

4. Wong PF, Craik S, Newman P, et al. Lessons of the month: a case of rhombencephalitis as a rare complication of acute COVID-19 infection. Clin Med 2020;20(3):293-294.

5. Mukherjee D, Sarkar P, Dubey S, Ray BK, Pandit A, Lahiri D. Ataxia as a presenting manifestation of COVID-19: report of a single case. medRxiv. Preprint posted online May 26, 2020. doi: 10.1101/2020.05.24.20103648

6. Armangue T, Spatola M, Vlagea A, et al. Frequency, symptoms, risk factors, and outcomes of autoimmune encephalitis after herpes simplex encephalitis: a prospective observational study and retrospective analysis. Lancet Neurol 2018;17(9):760-772.

7. Lancaster E, Dalmau J. Neuronal autoantigens: pathogenesis, associated disorders and antibody testing. Nat Rev Neurol 2012;8(7):380-390.

\section{Access the 2021 Annual Meeting Anytime, Anywhere}

Access $300+$ hours of content, $140+$ programs with syllabi, 25+ exclusive bonus presentations, and integrated CME testing-anytime and anywhere through March 31, 2022-with 2021 Annual Meeting On Demand! Visit AAN.com/AMOD to order yours today. 


\section{Neurology}

\section{SARS-CoV-2 Encephalitis Presenting as a Clinical Cerebellar Syndrome: A Case Report}

Katryn Oosthuizen, Elizabeth Christina Steyn, Lawrence Tucker, et al. Neurology 2021;97;27-29 Published Online before print April 14, 2021

DOI 10.1212/WNL.0000000000012051

This information is current as of April 14, 2021

\section{Updated Information \&} Services

References

Subspecialty Collections

Permissions \& Licensing

Reprints including high resolution figures, can be found at: http://n.neurology.org/content/97/1/27.full

This article cites 6 articles, 2 of which you can access for free at: http://n.neurology.org/content/97/1/27.full\#ref-list-1

This article, along with others on similar topics, appears in the following collection(s):

COVID-19

http://n.neurology.org/cgi/collection/covid_19

Encephalitis

http://n.neurology.org/cgi/collection/encephalitis

MRI

http://n.neurology.org/cgi/collection/mri

Information about reproducing this article in parts (figures,tables) or in its entirety can be found online at:

http://www.neurology.org/about/about_the_journal\#permissions

Information about ordering reprints can be found online:

http://n.neurology.org/subscribers/advertise

Neurology ${ }^{\circledR}$ is the official journal of the American Academy of Neurology. Published continuously since 1951, it is now a weekly with 48 issues per year. Copyright (C) 2021 American Academy of Neurology. All rights reserved. Print ISSN: 0028-3878. Online ISSN: 1526-632X.

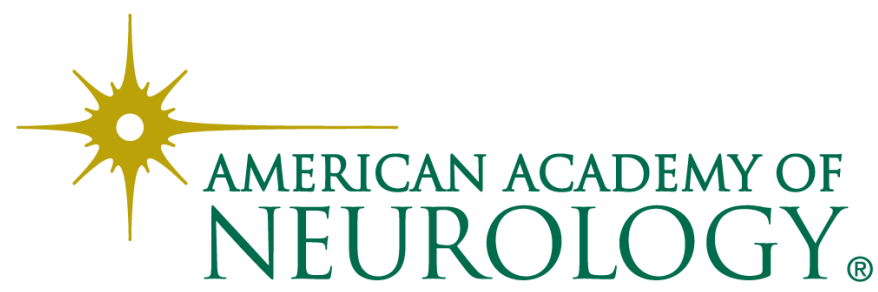

